\title{
Ethnocultural and Social Dominants of Pedagogical Education in Conditions of National Region
}

\author{
Natalia S. Morova ${ }^{1}$, Liudmila V. Kuznetsova ${ }^{2}$, Larisa V. Lezhnina ${ }^{1}$ \& Tamara V. Talanova ${ }^{3}$ \\ ${ }^{1}$ Mari State University, Yoshkar-Ola, Russia \\ ${ }^{2}$ Chuvash State Pedagogical University named after I. Ya. Yakovlev, Cheboksary, Russia \\ ${ }^{3}$ Chuvash State University named after I. N. Ulyanov, Cheboksary, Russia \\ Correspondence: Natalia S. Morova, Mari State University, Yoshkar-Ola, Russia. Tel: 8-836-245-5819. E-mail: \\ morovans@gmail.com
}

Received: February 21, 2015

Accepted: March 15, 2015

Online Published: April 29, 2015

doi:10.5539/res.v7n8p182

URL: http://dx.doi.org/10.5539/res.v7n8p182

\begin{abstract}
Teacher education at the present stage of its development undergoes changes because of the processes of globalization in general plus the influence of the Bologna process. This diminishes the level of Russian pedagogical experience. For the country like Russia, with its diversity of languages, traditions, ethnicities and cultures the pedagogical traditions of peoples are of a great importance for the modern teacher education. The main idea of the article is that "the civic task of education and the education system is to give each one absolutely mandatory amount of human knowledge, which is the basis of self-identity of the people" (from an article by Vladimir Putin "Russia: the national question"). The purpose of this article is to identify and study of ethno-cultural and social dominants of teacher education in the national region. The main approaches in considering the Russian system of teacher education in the article are defined as: evolutionary, axiological, regional approaches which allow us to consider the teacher education as a cultural-historical and ethno-cultural phenomenon. As an example for the analysis and synthesis of the Russian teacher education in historical perspective and actual measurements two national republics of the Volga region-Mari El and the Chuvash Republics are taken.
\end{abstract}

Keywords: dominants, ethnocultural and social dominants, pedagogical education, national region

\section{Introduction}

Global trends in the development of teacher education are both the reflection and the consequence of globalization affecting the sphere of culture and education. The content of teacher education, with a wide range of educational tasks is aimed at the development of the personality of a teacher and generally directed to the development of human culture, endowed with experience in the development and gaining cultural values of continued importance. The historical origins of the modernization of teacher education are people's pedagogical traditions, first schools, teacher training courses, specialized schools and institutes whose mission was to educate people on the basis of cultural, ethnic and cultural ideals with social significance. Objectives in this process are the dominant value bases of teacher education: ethno-cultural (language parity of the environment in which the individual is formed as a man of culture, knowledge of the own culture and the culture of other people living in the area where the future teacher studies; interethnic tolerance, social (humanistic orientation of educational activities; socio-cultural understanding of the importance of the mission of the teacher (outreach activities); development of skills in the creation of socially safe and conflict-free environment of the student (language, mental) and pedagogical organization of leisure activities of students.

The problem issue of the article is concentrated around finding the answer to the problem of the identification, scientific basis of socio-cultural and ethno-cultural landmarks of the modern teacher education in the national region, thus it is necessary to prove the historical-cultural and socio-economic conditions of the formation and development of teacher education in the national regions: the Chuvash and Mari Republics.

A live issue of the problem is based on the following factors: firstly, the modern teacher education that exists in isolation from the developed educational traditions of the people can't be regarded as an universal human phenomenon, it does not have foundation not taking into account the socio-historical factors; secondly, if the 
trends in the development of modern pedagogical education are a mere reflection of the processes of globalization, the modern teacher education as an universal phenomenon of culture, nationality, ethnicity and may be subjected to homogenization, that means losing "face" which reflects the universal and national (ethnic) values; thirdly, teacher education, meaning the biggest part of the society (teachers that teach and educate, children that learn and develop their intellectual and creative potential; future teachers that acquire knowledge and skills to work with children; parents that raise children in the family and share their life experience), should meet the expectations of the society, that is socio-cultural values must dominate; finally, fourthly, the modern teacher education as the part of culture should reflect the characteristics of the region in which it reflects so it means it should be ethno culturally oriented.

\section{Methods}

The main approaches in considering the Russian system of teacher education in the article are defined as:

- Evolutionary approach that allows us to consider pedagogical phenomenon in the cultural and historical implications;

- Axiological approach, which allows us to show the socio-cultural, ethnic and cultural value bases of teacher education and distinguish them as dominant, regardless of socio-economic and political circumstances;

- Regional approach, the implementation of which creates the possibility to specify the content of teacher education, taking into account socio-economic, historical, cultural, demographic characteristics of the region, focusing on the harmonization of the educational environment of students in the region, achieving the standard level of quality of education (Shvetsov, 2007; Schedrovitsky, 2000).

Research methods are:

- Theoretical-pedagogical analysis (general pedagogical, historical and pedagogical, ethno pedagogical), philosophical, sociological literature, normative and legislative acts in the field of education, including teaching education; study and generalization of pedagogical experience, analysis, synthesis;

- A sociological survey, interviews, discussions, study of results of educational activities of the institution of professional pedagogical education

\section{Results}

Institutionalization of teacher education in the national region should be considered from the point of view of the evolutionary approach as it involves the realization of the historical and pedagogical research based on the identification, collation, analysis and interpretation of ethno pedagogical facts.

\subsection{Formation Teacher Education in the Mari Region in Socio-Economic, Historical and Cultural Conditions}

The history of formation of teacher education in the Mari region is associated with the appearance of the first schools and we can identify a number of stages in the process (here we rely on periodization of the professor P. A. Apakaev (Apakaev, 2002)):

I stage - beginning of the XVIII century - the first middle of the XIX century-is remarkable with starting of the first schools on decision of the newly created Ministry of Education (1802) and the Educational District of the Kazan city (1803) in order to organize the systematic management of schooling. Thus was originated the first school for "alien peoples of Volga Region", in which there had been training Mari children among others. The school was open in 1707. In Kazan, at the Archbishop's House, and then, in 1719-1720, before the Metropolitan Bishop Tikhon, specially for the "Cheremis" had started the Novokhreschenskaya school, training 20 Mari children. Its organizers and the first teachers were literate Mari men, who had been taught by Russian priests. The example set by the Kozmodemyansk school is curious by the fact that the "Instruction for administrative duty" was speaking: "Educate children, help them to get on the path of truth, in order to make them enriched themselves with Russian customs, to make them know the Russian culture... It should be imposed as a duty on a priest to know the language of alien people. If they are Russians or Belorussians, they have to study assiduously the language of the area they live and they are fulfilling their service and the language their pupils are talking" (Petrova, 1994). The requirement was to study the culture of the people among whom the pupils were living;

II stage - the second half of the XIX century-1917—is characterized with stormy social movements, which provided formation and development of advanced democratic ideas in schooling, so as creation of the first schools with studying of the native languages. The experience of the Tsyganovskaya school, founded by its teacher M. Gerasimov in 1867, had been mentioned as significant in reports of N. I. Zolotnitskiy, inspector of Chuvash and Mari schools. In his report he made reference to the fact that the training on basis of Russian and Mari ABC books was giving a specially positive effect (Apakaev, 2002). The general experience of schools and 
teachers-practitioners was demonstrating the emphasized role of the pedagogical education in that period, its orientation to the satisfaction of the national social medium;

III stage - 20-th - 80-th years of the XX century - is including all most important periods in the history of the USSR. We can note those years as a period of a rapid development of the system of pedagogic professional training, that is its institutional trend on the basis of the national policy in the field of education: Higher Institutes of National education (1919); Eastern Pedagogical Institute (1921), training pedagogical staff for the territory of the Volga region, particularly for Chuvashia and Mari Regions; foundation of Yoshcar-Ola Pedagogical Institute (1932);

IV stage - 90-th of the XX century till nowadays - is remarkable by the renaissance of the democratic ethno-pedagogical fundamental principles in teaching and education of rising generation, so formation of educational specialists ready for ethno-pedagogic activity, in development of national and regional components for general school education and pedagogical education.

\subsection{The Formation of Teacher Education in the Chuvash Region in Historical and Cultural Conditions}

The periodization, which reflects the history of the development of teacher education in the Chuvash region corresponds to the processes taking place in the Mari region, due to the territorial proximity of the two national regions. But the first Chuvash schools emerged in the XVI century, and it was associated with the voluntary entry of the Chuvash people into the Russian state. They were the first monastic schools. But before they occur there were real teachers among Chuvash - people like storytellers, the wise old men. They were the guardians of the spiritual wealth of previous generations, "who somehow inherited and took over the abilities, skills, experience of previous generations" (Volkov, 1958). The first Novokreschenskie schools, particularly in Tsivilsk were opened on the territory of the Chuvash area in the 40's of the XVIII century. There was the instruction of the Synod and Novokreschenskiy office in the Regulation that declared to learn reading and writing in Russian and other spiritual matters but they had to "watch them, so that they do not forget their natural languages" (Petrova, 1994). There was listed the mother tongue in the first line of the graduation certificate. Taking this in consideration, we can conclude that the traditions of folk pedagogy of the Chuvash, who put above all respect and knowledge of native Chuvash language as the means of preservation and the future of the Chuvash people, were so meaningful and fruitful that the official pedagogy can't deny them. There was the teaching of singing, playing musical instruments, painting (the church painting). As we can see, in the middle of the XVIII century the Chuvash people were educated in schools and joined in the art and culture at the level of training of the cultural environment, though we can't say anything about joining in the national native culture as there was no system of language and cultural training at school.

Only with the opening in Simbirsk in 1868 the Chuvash teacher's school by I. Ya. Yakovlev, we could see the truly national system of education and training. Specific goals and ideas were put into the basis of the educational work of the teacher's school in Simbirsk that eventually were concretized in three ideas: first, "the development of indigenous dwellers should be sent to assimilate Christian ideals"- this idea was declared by I. Ya. Yakovlev as "the requirement of conscience and the heart"; second, "the idea of convergence and unification with the Russian people" (this idea expresses the communion to high culture, to the cultural traditions of the Russian people, in general human sense - the idea of unity, integrity of culture and the uniqueness of each); third, the introduction of the native language in the educational process of education as the main factor of education of the civilized man, thus we observe "the idea of knowledge of world culture through family, friends" (Yakovlev, 1998).

To implement these ideas in the educational process of Simbirsk Chuvash teacher's school there was ensured the increase of the culture level of the entire educational process, which contributed to the formation of Simbirsk Chuvash teacher's school as a national cultural center, and this was its social significance; a high level of professional pedagogical training of future teachers who organized the national artistic and aesthetic environment in school and the social effect was reflected in the development of national culture of the Chuvash on folk traditions.

Reviewing historical and pedagogical aspects of the problem of the article actualizes the community and unity of cultural space of teacher education and its existing processes in parallel. Despite some localization of educational practice in the neighboring national territories there occurred interrelationship and interdependence in teacher education.

Thus, outstanding representatives of the Chuvash people have made a significant contribution to the progressive principles of pedagogy and methods of training and education in the Mari region. We should name Mikhail Fedorovich Fedorov (1848-1904) the first in the list. He was a native of the village parish of Ityakovo 
Aydarovskoy Cheboksary County of Kazan province, a graduate from Samara teachers' seminary in 1873. In 1891 he moved to Tsarevokokshaisk and until the end of his life he worked in the city school, giving his teaching experience to Mari people. M. F. Fedorov wrote in his letter of November 22, 1901 from Tsarevokokshaisk to the Chuvash educator the following: "After I studied the manuals and textbooks for the Chuvash school, I had the idea that the system should be applied to other mixed ethnic schools since it's composed reasonably and achieves better results!" The serious attention was paid in the school on completion of a school library with works of the classics of Russian and foreign literature. A large number of works by Pushkin, Lermontov, Nekrasov, Turgenev, M. Reid, William Shakespeare and others were taken in.

As a corresponding member of the Society of Archaeology and Ethnography at Kazan University, M. F. Fedorov paid much attention to teacher knowledge of customs, traditions, rituals of Russian, Mari and Chuvash settlements, history and geography of the region. He can be called a follower of the great Russian teacher K. D. Ushinskiy and associate I. Ya. Yakovlev.

\subsection{Ethno-Cultural and Socio-Cultural Dominant Ideas as the Basis of the Russian System of Teacher Education}

Historical and pedagogical analysis of the formation and development of teacher education in the Republic of Mari El and the Chuvash Republic allows us to determine as its ethnic, cultural and social dominants the following:

- The parity of languages (Russian-Mari, Russian - Chuvash); knowledge of the culture of their own and other peoples living in the area where the future teacher studies; inter-ethnic tolerance;

- Humanistic orientation of teaching activities; understanding of the importance of socio-cultural mission of the teacher (educational work); acquisition of skills in the creation of social security and conflict-free environment of the student (language, mental) and pedagogical organization of leisure activities of students.

The given dominants are justified by the implementation of the following approaches to the determination of the content of teacher education in the national region:

1) The axiological approach. In accordance with it the teacher education is seen as a basic humanitarian value and a strategic resource of the personality of the teacher, it gives a measure of the concept, of the program from the point of common cultural and ethno-cultural, social and personally significant values.

2) The hermeneutic approach studies problems of interpretation and identification of deep meanings of pedagogical activity in its ethno-cultural conditions and social guidelines.

3) Linguistic and cultural approach updates the knowledge of the native language teacher, as a basis for teaching of communication that according to Hegel, is an indicator of high level of education and culture. In this context, understanding of the language as an assembler of culture (national culture) is a condition for the effectiveness of professional educator in the national community.

Based on these approaches, we can observe ethno-cultural education as the means and conditions for effective teaching activities in a multicultural environment, not outlined locally by ethno-cultural content today, but are characterized by the dominant ethnic and cultural features (language, traditions, mentality and others).

One of the areas of implementation of ethno-cultural education is the creation and testing of teaching kits on the Russian language for schools with Russian (non-native) and native (non-Russian) language learning. The thematic justification of this kind of experimentation is shown due to multilanguage nature of the educational process in schools (gymnasiums, lyceums) of the Republic of Mari El. We take into account not only the existence of the native features of (local) language as one of the state and related languages (Finno-Ugric languages), but also languages of other nationalities living in the territory of the republic. Ethno-cultural education is as the foundation of civil and inter-ethnic harmony in Russian society.

The results of the polls show the interest of students of a pedagogical high school and the future teachers to national problems caused by cases such as intermarriage and, enshrined in the Declaration of the Rights of the Child, the right to nationality of the parents, labor migration, the demand of folk traditions, rituals and festivals, handicrafts in the society, finally, the implementation of laws on languages in the national republics. The opinion poll, conducted in the Chuvash Republic among the students (the future teachers) in the course of ethno-cultural project "Ethnic and cultural development and international relations" showed the following:

- The questions of the survey, which begin with the statement: "I am a man who loves his people, but respects the language and culture of other nations" were responded positively by $78 \%$ of the future teachers; "I am a man who is ready to deal with any representative of any other people in spite of national differences" were responded positively by $66 \%$ of the future teachers, "I am a man who always finds an opportunity to negotiate peacefully in 
ethnic disputes"- $61 \%$. The conclusion here is that the vast majority has showed a positive attitude towards themselves and others;

- The questions of the survey, which begin with the statement: "I am a man who believes that any means of protection of the interests of their people are good" were responded positively by $17 \%$; "I am a man who often feels his superiority over other people"- $18 \%$; "I am a man who considers that it's strictly necessary to preserve the purity of the nation"- $23 \%$; "I am a man who considers that his nation has the right to solve its problems at the expense of other nations"- $10 \%$; "I am a man who believes his people are more talented and developed compared with other peoples"-10\%; "I am the person who finds it is necessary to "purify" the culture of his people from the influence of other cultures"-10\%; "I am-a man who believes that on his land all rights to use natural and social resources should belong only to his people" $-9 \%$. The conclusion: the exaggerated (hypertrophic) attitude towards their nation, almost nationalism is reflected in a small proportion of the future teachers, despite the fact that the humanitarian component in the content of teacher education plays an important role.

These figures indicate that the state of interethnic relations in the Chuvash Republic is mostly characterized by tolerance and mutual respect. It's characteristic that the vast majority of respondents disagreed with the statement that all rights to use natural and social resources on their land should belong only to their people. The choice of this response confirms the thesis about conflict-free, tolerant and friendly nature of the Chuvash people (in the survey $67 \%$ of the Chuvash among all respondents were involved).

A survey conducted in the Republic of Mari El, where there are Russians (45.1\%), Mari (41.8\%), Tatars (5.5\%) and other peoples $(7.6 \%)$ also testify that future teachers are satisfied with the state of international relations. Answers to the question: "How do you treat people of other nationalities?" revealed the following: $68.5 \%$;-"good", $24.5 \%$ - satisfactory; $2.6 \%$-"unsatisfactory"; $4.4 \%$-"difficult to answer".

1,564 people from all cities and regions were surveyed during the study and the results reflect the following: $55.6 \%$ of the respondents are fully satisfied with the state of interethnic relations, $31.4 \%$-in part; $5.1 \%$-not satisfied; $7.9 \%$ - undecided.

Thus, taking into consideration the example of two republics of the Volga region, the real state of international relations which is the environmental factor of development of teacher education, can be estimated as harmonious. However, this gives grounds for ignoring the real processes of globalization, which may negatively affect the maintenance of cultural and ethnic identity of the individual. The main aid to prevent it is inter-ethnic tolerance that comes out of respect for the cultural diversity of humanity.

\section{Discussion}

Problems of teacher education, its formation and development are examined in the works of P. A. Apakaev, G. N. Volkov, T. N. Petrova and others. They consider historical, cultural and ethno-cultural factors that contribute to the specificity of nationally oriented pedagogical schools and systems. Environmental factor that plays a significant role in guiding teacher education is the subject of research of L. V. Kuznetsova, G. N. Shevtsova, and G. P. Shchedrovitsky. However, the identification and study of ethno-cultural and social dominants of teacher education, developing in a national region, has not been the subject of scientific research.

\section{Conclusion}

Solving the problem of revealing and scientific backing of socio-cultural and ethno-cultural landmarks of teacher education in the region is connected with consideration of the national origins of teacher education as an integral part of the spiritual culture of any nation. The objective opportunity for scientific forecasting in pedagogical science and education was established by the history of their development. According to the scientist of culture studies A. I. Arnoldov "to be a prophet is a difficult and thankless task. But it is necessary to think about the idea of purposeful historical development in order to create history and a new picture of the world" (A. I. Arnold, 1997). In this context, the revealing of ethnic, cultural and social dominants of the teacher education in the national region allows us to see the general in specific and specific in general, in other words historical and pedagogical parallels, their evolution in the modern teacher education.

\section{References}

Apakaev, P. A. (2002). Education and educational movement in the Mari region (historical and pedagogical essays). Yoshkar-Ola.

Arnoldov, A. I. (1997). The civilization of the coming century (cultural reflections). Moscow: Graal.

Kuznetsova, L. V. (2014). National-cultural learning environment of the student. Cheboksary: Chuvash state 
pedagogical university.

Morova, N. S. (2011). The success of the training of professionals-In alliance with the employer. Rector of the university, 4, 60-61.

Petrova, T. N. (1994). School and education of Chuvashia in the XIII century in Cheboksary. CSPU.

Putin, V. V. (2012). Russia: The national question. Retrieved from $\mathrm{http} / /$ surkov.info/statya-putina-rossiya-nacionalnyj-vopros/

Schedrovitskiy, G. P. (2000). Regional aspects of management.

Shvetsova, G. N. (2007). Theoretical bases of management of the regional educational system. Yoshkar-Ola: Moscow Open Social University (Institute).

Volkov, G. N. (1958). Chuvash folk pedagogy. Cheboksary: Chuvashgosizdat.

Volkov, G. N. (2009). Ethnopedagogical pansophy. Elista: Kalmyk State University.

Yakovlev, I. Ya. (1998). My Life: Memories. Cheboksary: Republic.

\section{Copyrights}

Copyright for this article is retained by the author(s), with first publication rights granted to the journal.

This is an open-access article distributed under the terms and conditions of the Creative Commons Attribution license (http://creativecommons.org/licenses/by/3.0/). 